\title{
Study on the Financing Insurance System of College Student' Entrepreneurship
}

\author{
Chen Zhou \\ Wuhan University of Technology \\ Wuhan, China
}

\author{
Qian Xia \\ Wuhan University of Technology \\ Wuhan, China
}

\begin{abstract}
Since the summer Davos in September 2014, there has been a nationwide upsurge of mass entrepreneurship and innovation. As the most innovative and dynamic generation, college student' entrepreneurship has become one of the hottest topics. However, there are many difficulties for college student to start their own business. Based on the survey data analysis and the establishment of financing insurance as the path, this paper integrates the resources of Banks, insurance companies, schools and the government to find the biggest difficulty for college student to start their own businesses, and tries to solve the financing dilemma of college student to start their own businesses by insurance. This paper integrates the financing of insurance, loans and funds, and combines the resources of Banks, insurance companies, schools and governments to achieve a win-win situation. This paper focuses on the analysis of the rights and obligations of each subject in the start-up financing insurance for college student, and provides Suggestions on the improvement of the legal system of start-up financing for college student in terms of legislative principles, legislative system and legislative content.
\end{abstract}

Keywords-college students' venture; capital financing insurance; legal system; private funds

\section{INTRODUCTION}

The 21 st century is an era of innovation. For China, its economic development is in the stage of structural transformation, which requires innovation, development and entrepreneurship to inject fresh impetus into the structural transformation of China's economy. In September 2014, Premier Li Keqiang first proposed "mass entrepreneurship" and "mass innovation" at the summer davos BBS. In 2017, General Secretary Xi Jinping pointed out at the annual central economic work conference that "we need to strengthen incentives and encourage innovation and strengthen the internal driving force of micro actors." In the face of the already formed wave of mass entrepreneurship and innovation, it has gradually developed and reached the whole people. As the main builders of the future of the society, the hope of the motherland, the most dynamic and innovative thinking of college students, expect to be able to blend in and play a role.

College students' entrepreneurship has attracted public attention since the end of the 20th century.

However, the enthusiasm of college students to start their own business is confronted with a harsh reality. Less than $10 \%$ of the success rate of entrepreneurship, high barriers to entrepreneurship, financing difficulties... Become the bottleneck of college students' entrepreneurship which stop college students from starting businesses. In this case, although the state has put forward a series of policies to encourage college students to innovate and start their own businesses, it aims to provide a good platform for college students to innovate and start their own businesses actively. However, the reality is that most of the national policies on entrepreneurship of college students focus on the level of tax reduction and exemption, with a single form and limited effect, and lack of attraction for college students to carry out entrepreneurial activities.

On the whole, at the present stage, college students in China are facing great difficulties in starting their own businesses. The establishment market is still not perfect, and it is urgent for the country and society to work together to create a better entrepreneurial environment for college students.

\section{CurRent Situation of College Student ENTREPRENEURSHIP}

The financing insurance for college student' entrepreneurship needs to follow the will of college student and understand the market situation of college student' entrepreneurship. This paper analyzes the current situation of college student' entrepreneurship by combining the current situation of college student' entrepreneurship and through the survey data in the project during college years. 


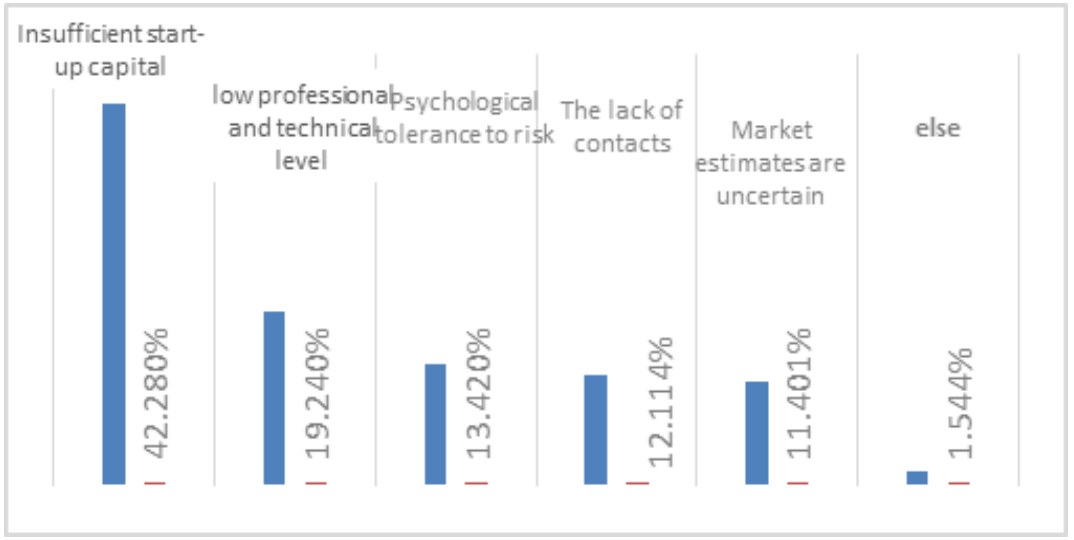

Fig. 1. The survey results show the biggest difficulties for college student to start their own business.

This paper explores two main influencing factors of college student' entrepreneurship: one is the influencing factor of college student' entrepreneurship and establishment, and the other is the influencing factor of the success rate of college student' entrepreneurship.

\section{A. Factors Influencing College Student' Entrepreneurship}

The main influencing factors for college student entrepreneurs to transform their entrepreneurial intention into entrepreneurial action include venture capital, entrepreneurship education, entrepreneurship policy, family environment and other factors [1]. Survey data show: More than $40 \%$ of students think that their own businesses the biggest problem is lack of start-up capital, venture capital has become one of the main factors of college student' entrepreneurial intention (see "Table I"), its direct impact on the college student if entrepreneurs can convert their entrepreneurial intention into action, so think is very important to solve the problem of college student' venture capital, this paper present a total of about 26.253 million people full-time college student in Hubei province, graduated from two years of college student about 13.3906 million people, according to statistics, $29 \%$ of college student interested in entrepreneurship, has strong entrepreneurial intention, About 11.5 million people in the nation, and the real entrepreneurship rate is less than $5 \%$, less than 2 million people, about 950 defined by college student with entrepreneurial intention and did not translate into practical action, according to the survey data, can be calculated that about 3.8 million of people think that students: what's the most difficult is to start their own businesses insufficient funds, this paper holds that if the population to $10 \%$ by college student venture financing venture financing insurance to solve the problem, will bring a fresh and creative power for the society. In addition, entrepreneurship education is a hot topic in the current university education. The service system of college student' entrepreneurship financing insurance designed in this paper also includes specialized entrepreneurship education courses.

\section{B. Influencing Factors of Entrepreneurial Success Rate of College Student}

The success rate of college student entrepreneurs after they start their business and take practical actions is very important for college student' start-up financing insurance. The main factors influencing the success rate of college student' business startups include: entrepreneurship type, personal ability, entrepreneurial market environment, entrepreneurial policies, etc. For college student' entrepreneurship at the present stage, the high-tech content of entrepreneurship is relatively low, which fails to meet the needs of innovative reform of the country [2]. According to the data of China insurance regulatory commission, the loan performance rate of science and technology enterprises exceeds $95 \%$, and the average annual net profit of science and technology companies is about $25 \%$.Both figures are well above the average for the average business. Therefore, this paper argues that the financing insurance for college student' entrepreneurship should limit college student' entrepreneurship (projects) to the scope of science and technology and innovation, so as to meet the expectations of national structural reform and improve the success rate of entrepreneurship. At the same time, personal ability is also a key influence factors of college student' entrepreneurial success, based on the design of college student venture financing insurance when also considering the reasons, the recommended way to school, college student better to absorb entrepreneurs, soft information of college student' entrepreneurial enterprises (projects), to improve the quality of college student' entrepreneurs and their enterprises (projects), improve the success rate of the college student' entrepreneurial risk control of college student' venture financing the insurance. 


\section{FEATURES OF UNDERGRADUATE VENTURE FINANCING INSURANCE}

\section{A. "Loan-Insurance-Fund" Combination of Compound Insurance}

College student' start-up financing insurance aims to solve the financing difficulties of college student' start-up and the risk guarantee of college student' start-up. Its establishment mode includes not only ordinary insurance but also loans. To cover insurance and loan at the same time, this paper argues that college student' venture financing insurance can take the insurance company set up subsidiary specializing in the form of insurance fund, on the one hand, separating the finance and insurance, draw lessons from the traditional mode of financing of insurance, share the risk, on the other hand, the isolation of direct connection between bank and university student entrepreneurs, the greatest degree of reduce the risk of bank funds [3].

\section{B. "Half Profit and Half Public Welfare" Insurance}

College student' start-up financing insurance adopts the insurance mechanism of half-profit and half-public welfare, separating profitability from public welfare, which is reflected in the free screening and investment of government and school, and also includes the special public welfare service system set up by the main insurance company (this part of the fund shall be jointly undertaken by the insurance company and the government). Profitability is reflected in the investment of Banks and insurance companies and the collection of insurance premiums. This kind of "semi-profit and semi-public" insurance mechanism, on the one hand, the state supports and encourages college student to start their own businesses, which has certain policy orientation and needs the support of public welfare forces; on the other hand, entrepreneurship is a market-oriented behavior and needs the participation of market-oriented financial institutions in financing.

\section{C. "Government-School-Bank-Insurance Company" Four- Party Cooperative Insurance}

Due to its special insurance nature, college student' venture financing insurance needs to introduce a multi-party cooperative management system, in which the government is the public investor [4]. The school is responsible for public welfare investment and the first screening. Banks are forprofit investors; an insurance company is a for-profit investor and insurer; the insurance fund trustee established by the insurance company (an independent subordinate organization with independent legal subject qualification) is responsible for fund financing and operation management. Multi-party cooperation, give full play to the advantages of their own resources, to share risks, multi-party win-win business objectives.

\section{D. "Three Lessons, Two Supervision and One Mechanism" Service Support Insurance}

The special public welfare service system included in the financing insurance for college student' entrepreneurship refers to the service system of "three courses, two supervision and one mechanism". The three courses are management course, accounting course and policy course, respectively, which teach college student the necessary skills of entrepreneurship from three aspects. The two kinds of supervision are respectively financial supervision and management supervision, which respectively supervise college student' start-up companies (projects) from two fields to avoid unnecessary entrepreneurial risks as much as possible. Circuit breakers is a mechanism, that is, refers to the college student' entrepreneurial company (project) once the assets less than $50 \%$ of the original financing funds, private equity fund trustee institution shall have the right to evaluate college student' entrepreneurial company (project), once the assessment result is "not appropriate to continue operating" immediate termination of financing, auction on college student' venture company (project), guarantee the lowest money-back guarantee mechanism. On the one hand, the service system of "three lessons, two supervision and one mechanism" will provide better and more professional education courses to help college student entrepreneurs to better run start-up companies (projects). On the other hand, various security measures are used to effectively control the risks of college student' start-up companies (projects).

\section{THE CONSTRUCTION OF THE FINANCING INSURANCE SYSTEM FOR COLLEGE STUDENT}

\section{A. Eestablishment of Collection System}

The college student start-up financing insurance designed in this paper has three repayment parts: the first part is the insurance operation period, which lasts for three years, and the payment is $30 \%$ of the net profit of the company (project).The second part is that at the end of the loan, the loan repayment rate is $115 \%$. The third part is that after the loan is returned, the insurance fund trustee established by the original insurance company retains $5 \%$ shares of each college student start-up company (project).

The college student start-up financing insurance designed in this paper is expected to have successful, more successful, normal, more failure and failure of five kinds of college student start-up companies (projects).According to the data from the Shanghai regulatory bureau of the China insurance regulatory commission, the average annual profit of small and medium-sized science and technology enterprises similar to those in this paper is $25 \%$.

Expected effect in the table refers to the paper is expected to the operations of college student' entrepreneurial enterprises (projects), expected profit for the under different operating conditions is expected to average annual profits, expected rate estimates, according to the measure data, not fine but has a certain reference value, the recovery of funds is under prescribed the reimbursement mechanism of capital recovery and the proportion of the principal, the percentage than recovery is money recovery with expected product, are used to calculate the total project funding recovery than (see table).The total average fund recovery ratio of the project is $109 \%$, in which the bank gets $57.5 \%$, the insurance company gets $46 \%$ for investment, the insurance company gets $2 \%$ for premium income, the insurance fund trustee gets $4.5 \%$ for 
operating expenses, and the insurance fund trustee keeps 5\% equity of some successful projects. On the whole, it achieves the goal of win-win for all parties expected in this paper and makes all parties willing to participate in this project.

TABLE I. EXPECTED EARNINGS

\begin{tabular}{|l|l|l|l|l|l|}
\hline \multicolumn{1}{|c|}{ Serial number } & Expected effect & Expected profit & Expected & Fund recovery & \multicolumn{1}{|c|}{ Specific recovery } \\
\hline A & successful & More than $40 \%$ & $10 \%$ & $170 \%$ & $17 \%$ \\
\hline B & good & $20-40 \%$ & $20 \%$ & $140 \%$ & $28 \%$ \\
\hline C & normal & $10-20 \%$ & $20 \%$ & $120 \%$ & $24 \%$ \\
\hline D & Bad & $-10-10 \%$ & $25 \%$ & $100 \%$ & $25 \%$ \\
\hline E & failure & less than $-10 \%$ & $25 \%$ & $60 \%$ & $15 \%$ \\
\hline
\end{tabular}

Data sources and findings of the author's own project.

\section{B. Rrisk Control}

In this paper, the design of college student' venture financing insurance system of risk control includes two main areas: first, the "double filter", which refers to the entrepreneurs to apply for college student, organized by the school screening for the first time, the main content of the audit is: college student personal Circumstances, personal ability, personal credit, personal character such as college student entrepreneurs personal information; The feasibility of undergraduate start-up companies (projects) at the theoretical level and the professional level. The college will recommend the project after screening, and the insurance fund trustee will organize professional risk assessment and market assessment professionals to conduct feasibility analysis on the market and practical level. After two levels of assessment, in combination with college student' entrepreneurial company (project) of soft and hard information, comprehensive and in-depth investigation and screening, professional, to ensure quality of every college student entrepreneurial company (project), and improve college student in college student' venture financing insurance startup success rate (projects), reduce the college student' venture financing insurance funds, the risk of implementation of risk control. Second, "three lessons, two supervision and one mechanism" service system. The whole, this paper designed by college student venture financing, insurance, made a special setting in terms of risk control, the two major risk control links, respectively from the college student' entrepreneurial company (project) quality and operation management, the two aspects of risk prevention and control, this paper argues that the two links will improve the success rate of entrepreneurship, not only need to set up in this insurance, at the same time worth extending application.

\section{Construction of Insurance Fund System}

Financing is one of the special aspects that college student' venture financing insurance is different from other ordinary insurance, and it is also one of the important links of college student' venture financing insurance. The financing of college student' start-up financing insurance is a single subordinate institution established by the original insurance company - the management team of insurance fund. As the collection and management team of insurance fund, it conducts financing from all parties. Investors with a total of four college student venture financing insurance: the first is the bank, the bank gives priority to the investor, one of its capital contribution ratio of $50 \%$, with the insurance fund custodian for loan relationships, models for ordinary loans taken by Banks in financing only in the final loan return with the return, return the money to the original bank $115 \%$ of investment funds, its annual interest rate is $4.8 \%$, slightly higher than the normal loan interest rate of the bank. Second is the insurance company, insurance company mentioned including two one is the original insurance company, the other is a reinsurance company, its take $25 \%$ and $15 \%$ of investment funds, the final repayment than $115 \%$ repayment rate is consistent with the bank, in addition, the original insurance company will charge a total of $5 \%$ of the insurance fees, the total capital of $2 \%$ annual rate of $0.6 \%$, with roughly the same level of the enterprise property insurance rates).The third is the school, the school contribution $10 \%$ for public welfare contribution, no return. The fourth party is the government. The government is mainly responsible for the payment of administrative expenses of "three courses", which is also a part of the investment. It is a public welfare investment, aiming to create more professional and high-quality entrepreneurship courses training for college student. The four parties jointly participate in investment, form a four-party investment mechanism, make full use of the advantages of all parties, in order to achieve a win-win situation.

\section{Construction of Insurance Standard System}

Right now, the main legal system about insurance in China is, "insurance law"; it is overall legal norm, Circ is right partial insurance to plant concerned content to establish industry norm. It is a system of laws and regulations combining macro and micro. This article thinks that this kind of present legal standard system suits our country national condition better, easy to manage the operation of insurance industry. Entrepreneurship for college student in terms of financing, insurance, this paper argues that can be set up normative documents of the line, college student' venture financing with the existing various insurance is planted all kinds of characteristics of differences, this danger to plant belongs to the relatively novel, innovation degree is higher is planted, at the same time, during the period of founding, need to standardize the main body of this danger to plant, concrete content, in order to ensure stability of planted when set up. Therefore, it is necessary to use separate regulations to regulate the content of such risks, and the Circ shall set up "interim measures for college student' start-up financing insurance" to supervise and guarantee college student' startup financing insurance. 
of the college student' entrepreneurship and management process, mode of operation for regulatory control, reduce risk, achieve the highest success rate, the benefit maximization, achieve the goal of win-win.

f) Multiple regulatory principles: In order to realize risk control, it is necessary for the insurance fund trustee of the subordinate organization of the original insurance company to supervise the operation, management and financial situation of the undergraduate start-up company (project). At the same time, Banks and insurance companies are also required to supervise and supervise the management of insurance fund by insurance fund custodians. The government is also required to supervise the whole college student' start-up financing insurance. The supervision and supervision at three levels form a hierarchical supervision system from the micro level to the macro level.

g) Two-way selection principle: Some scholars who study college student' entrepreneurship insurance think that the insurance related to college student' entrepreneurship needs to be set up as compulsory insurance. However, this paper thinks otherwise. College student' entrepreneurship is a market behavior, and the market behavior needs to be based on the willingness of both parties. The insurance of compulsive pay on the market is planted danger, main purpose has two, it is social welfare, another is social security. However, college student' start-up financing insurance does not belong to this category. In order to control risks, mandatory financing is obviously not appropriate. Therefore, this paper believes that college student' start-up financing insurance should be established on the basis of mutual selection between the two sides.

2) Subject qualification: Each main body qualifications: the main body is a college student entrepreneurship is one of the most core content in finance insurance, specification of subject qualification and defined, is conducive to improve the success rate of the college student' entrepreneurial company (project) to guarantee the safety of the college student' venture financing funds, to improve the stability of the college student' venture financing insurance. The improvement of the insurance system of college student' start-up financing insurance first needs to clarify the principles of the legal system. There are certain differences between college student' start-up financing insurance and ordinary insurance types. This paper believes that the legal system of college student' start-up financing insurance needs to follow the following principles:

a) College student: This paper has made the following restrictions on the subject qualification of college student: (1) college student refer to undergraduates or masters graduates within two years after graduation; Or undergraduate or postgraduate students who have been approved by the university to participate in entrepreneurship. (2) this insurance is only applicable to full-time undergraduates.

b) Undergraduate start-up companies (projects): In this paper, the following provisions are made for the start-up is bigger than ordinary loans, therefore, need the main body 


\section{LEGAL RELATIONS, RIGHTS AND OBLIGATIONS}

companies in the graduate start-up financing insurance: (1) the legal representative and the person in charge of the graduate start-up companies (projects) shall be the college student specified in this insurance. (2) all employees or members of the undergraduate start-up company (project) shall have more than $1 / 2$ of the undergraduate students covered by this insurance. (3) undergraduate start-up companies (projects) should be established or about to be established. (4) the registered capital of a university student start-up company shall not exceed 1 million yuan. (5) the business content of the undergraduate start-up company (project) should be related to the applicant's major during university or postgraduate study. (6) undergraduate startups (projects) with various innovative achievements and patents are preferred. (7) college student' start-up companies (projects) are concerned with strategic emerging industries and priority is given to key state-supported industries.

c) The insurer: This paper has the following Settings for undergraduate venture financing contractors (original): (1) the original insurer should be a public insurance company or a special government guarantee agency. (2) the original insurer does not have the primary purpose of profit in this insurance. (3) the original insurer shall be qualified and have experience in the establishment of an insurance fund. (4) the original insurer needs to establish an insurance fund trustee; The trustee of insurance fund shall be a single subordinate institution established for the original insurer, which has an independent legal status. There are no special regulations for underwriters and insurance companies. Commercial insurance company or public insurance company, or special government guarantee agency can be used as the re-insurer of student start-up financing insurance.

d) The bank: In this paper, the following provisions are made for the Banks in the undergraduate venture financing insurance: (1) the investor of the undergraduate venture financing insurance, the bank, needs to be a national commercial bank or policy bank. (2) the bank shall not have direct contact with university student entrepreneurs and university student start-up companies (projects) in the financing insurance for university student start-ups. (3) the bank needs to make loans to the insurance fund set up by college student' start-up financing insurance for a long time to ensure the stability of the capital source.

e) Universities, government: For universities and governments, this paper has the following Settings: (1) recommended universities should be full-time undergraduate universities. (2) financing colleges and universities shall be consistent with the recommended colleges and universities, and the investment funds shall be free funds and shall not seek recovery or return. (3) participate in the investment of the government, government agencies, the need to have the national law provisions of the administrative subject qualification, according to the national law provisions free, long-term, fixed for college student venture financing insurance set up the insurance fund injection.
The legal relationship between the main body: the main body depends on the legal relationship to form the main body network of college student venture financing insurance. In order to realize standardized, specialized and unified management and realize efficient supervision, the legal relationship between various subjects should be stipulated to avoid the phenomenon of disordered relationship and ineffective management.

Rights and obligations of each subject: rights and obligations are the basic content of the legal relationship. Only when rights and obligations are established can the subjects of all parties intuitively understand the legal provisions, fulfill their obligations, protect their rights and achieve a win-win situation for all parties to the greatest extent. The fourth chapter of this paper has focused on the analysis of the main rights and obligations of each subject, not comprehensive, in the establishment of legal norms, it is necessary to comprehensively regulate this [6].

This paper holds that the establishment of a class of insurance risks requires the standardization and protection of laws. This section will analyze the rights and obligations of each subject in the start-up financing insurance for college student. Through the analysis of the rights and obligations of each party, the paper lays a foundation for the improvement of the legal system of financing insurance for college student.

\section{A. Rights and Obligations of the Bank}

The bank plays a single role in the financing insurance of college student' start-up. It only has a long-term loan cooperative relationship with the insurance fund trustee, and is not associated with other subjects. The bank has the following rights: The right to request the insurance fund trustee to return the principal and interest on schedule; Supervise the right of the insurance fund trustee to use the loan, and supervise whether the loan is fully distributed to qualified college student' start-up companies (projects); The insurance fund trustee has the right to terminate the contract if it fails to perform its obligations as agreed in the contract. The bank's obligations mainly include: Unilaterally terminate the loan contract without any reason. What is different from ordinary loan is that the bank and insurance fund trustee sign long-term and installment loan contract in college student' venture financing insurance.[7] The bank and the insurance fund trustee will establish a long-term cooperative relationship, so as to guarantee the stability of the capital source of college student' start-up financing insurance and avoid entering the situation of no capital.

\section{B. Rights and Obligations of the Insurance Company}

In order to guarantee the stability of insurance, reinsurance link is added in the college student' start-up insurance. Therefore, this paper includes two insurance companies, the original insurance company and the reinsurance company.

There are four levels of relationship between the original insurance company and college student' start-up financing insurance. The second layer is to inject capital into the 
insurance fund; the third layer is to set up insurance for loans of college student' start-up companies (projects). The fourth layer is to establish reinsurance relationship with reinsurance companies. According to the legal relationship of the original insurance company, it mainly has the following rights: The right to request the insurance fund trustee to turn in invested funds and dividends on schedule; The right to collect insurance fund custodian institutions to pay premiums on behalf of college student' entrepreneurship (project) as agreed in the contract; Request the reinsurer to amortize and obtain the right as stipulated in the contract. The main obligations of the original insurance company include: In accordance with the insurance contract, if the college student fail to start their own business, they shall request the insurance fund trustee to terminate the loan contract with the college student' start-up company (project) and use the investment capital and profits of the insurance fund insurance company to repay the loan; On schedule, according to the contract, pay reinsurance premiums to the reinsurance company.

Reinsurance companies in college student' venture financing insurance only with the original between insurance companies and insurance fund custodian have direct legal relationship: reinsurance companies in college student' venture financing insurance agreement with a primary insurance company needs to reinsurance contract, including investment in the insurance contract and insurance two parts, respectively, and the original insurance company and its subsidiary insurance fund trustee legal relationship. The main rights of the reinsurance company include: The right to request the insurance fund trustee to return the invested capital and dividends as agreed; the right to collect from the original insurance company; the right to supervise the operation of funds of the insurance fund trustee. The main obligations of the reinsurance company include: According to the insurance contract, if the college student fail to start their own business, they shall make compensation to the insurance company in proportion to the investment capital and profits of the reinsurance company in the insurance fund.

\section{Rights and Obligations of the Insurance Fund Trustee}

Insurance fund trustee is a subsidiary of the original insurance company, in college student' venture financing insurance is a central organization, responsible for the parties subject to related, its acted an important role in college student' venture financing insurance, its legal relationship with all the body directly, it does not have the body of the independent legal person qualification, but an independent capacity for civil conduct, can be used as an independent legal subject (organization) for each activity. The main legal relations between the insurance fund team and the college student' start-up financing insurance include: the loan relationship formed with the bank, the financing relationship formed with the original insurance company and reinsurance company, the public investment relationship formed with the school, the loan relationship formed with the start-up company, etc. The main rights of an insurance fund trustee are as follows: The right to request the insurance company to conduct financing on schedule; The right to request the school to inject funds on schedule; The right to request the startup company to return the loan and interest; The right to receive a certain percentage of the net profit of the startup company as agreed; Supervise the rights of college student' start-up companies; College student have the right to unilaterally terminate the loan agreement if the company is not well managed. The main obligations of the insurance fund trustee are: Return the bank loan and interest on schedule; pay premiums to the insurance company; Pay dividends to the insurance company on schedule; Give funds to college student' start-up companies on schedule; Supervise the operation of college student' start-up companies, and make emergency measures in time according to the actual situation.

\section{Rights and Obligations of the School}

School is one of the commonweal parties in college student' start-up financing insurance, and its role is as mentioned above, including audit and public capital injection. In college student' start-up financing insurance, school only has direct legal relations with start-up companies (projects) and insurance fund custodians. The main rights of the university in the financing insurance of college student' entrepreneurship include: Review the rights of college student' entrepreneurship insurance enterprises (projects) and college student' entrepreneurs; the right to recommend undergraduate start-up insurance enterprises (projects) to the insurance fund trustee. The main obligations of the university in the financing insurance of college student' entrepreneurship are as follows: The obligation of ensuring the quality of college student' entrepreneurship insurance enterprises (projects) and college student' entrepreneurship and strict audit; Inject funds into public welfare according to the agreed amount of funds (according to the amount of funds applied by successful college entrepreneurs recommended by them, inject funds into the agreed proportion); Publicize the financing insurance for college student with entrepreneurial intention or established enterprises; Provide space for professional education courses for college student who are entrepreneurs.

\section{E. Rights and Obligations of the Government}

The government, like schools, is one of the public welfare parties in college student' start-up financing insurance. Its functions mainly include free professional entrepreneurship courses and interest rate subsidies. In the start-up financing insurance for college student, the government only has direct legal relations with entrepreneurs and Banks. The government has the following rights in the start-up financing insurance for college student: Supervise the operation of start-up financing insurance for college student; Request college entrepreneurs to participate in the designated professional training courses. The main obligations of the government in the financing insurance for college graduates are as follows: Provide free professional courses for college graduates; subsidize interest rates on bank loans. 
the legal system of college students' start-up financing insurance and lay a solid foundation for the establishment of college students' start-up financing insurance.

\section{REFERENCES}

[1] Bernhofer L B, Li J. Understanding the entrepreneurial intention of Chinese students: The preliminary findings of the China Project of "Global University Entrepreneurial Spirits Students Survey" (GUESSS) [J]. Journal of Entrepreneurship in Emerging Economies, 2014, 6(1):21-37.

[2] Olaosebikan O, Adams M. Prospects for micro-insurance in promoting micro-credit in sub-Sahara Africa [J]. Qualitative Research in Financial Markets, 2014, 6(3):232-257.

[3] Lounsbury M. Collective entrepreneurship: the mobilization of college and university recycling coordinators [J]. Journal of Organizational Change Management, 1998, 11(1):50-69.

[4] Quadrini V. Entrepreneurial financing, savings, and mobility [J]. Advances in the Study of Entrepreneurship Innovation \& Economic Growth, 2001, 13:71-94.

[5] Taylor M. Risky Ventures: Financial Inclusion, Risk Management and the Uncertain Rise of Index-Based Insurance [M]// Risking Capitalism. 2016.

[6] Hong Q. The major difficulties and countermeasures of current university graduates' entrepreneurship in China [J]. Journal of Chinese Entrepreneurship, 2013, 3(3):228-239.

[7] Yao X, Wu X, Long D. University students' entrepreneurial tendency in China: Effect of students' perceived entrepreneurial environment [J]. Journal of Entrepreneurship in Emerging Economies, 2016, 8(1):60-81 fact, direct contact with college student' entrepreneurial company (project) of only three of the main body, its main purpose is to reduce the college student entrepreneurial company (project) of the contact surface, avoid to produce communication misunderstandings between the parties, guarantee the stability of the college student' entrepreneurial finance insurance, reduce the risk of college student venture financing and insurance. In the financing insurance of college student' start-up, the main rights of college student' start-up companies (projects) are as follows: The right to claim repayment from the insurance company after the failure of the college student' start-up company (project); as the subject, sign the right of financing insurance for college student with an insurance company. In the financing insurance of college student' start-up, the main rights of college student' start-up companies (projects) are as follows: Pay a certain percentage of the net profit as agreed; Upon maturity of the loan, the principal and interest shall be repaid in accordance with the agreement.

\section{CONCLUSION}

This paper analyzes the current situation of college students' entrepreneurship and financing, and proposes to solve the difficulty of college students' entrepreneurship financing by means of financing insurance. Overview of the main body of college students' venture financing insurance is defined, on college students' venture financing insurance system are briefly analyzed, and argues that the establishment of insurance that need to be legal norms, so the start-up financing insurance legal system for college students proposed legislation principle and legislation system, the main content of the two aspects of the proposal. It is hoped that it can provide some enlightenment for the formulation of 